\title{
Article/Artigo
}

\section{Anti-Toxocara antibodies detected in children attending elementary school in Vitoria, State of Espírito Santo, Brazil: prevalence and associated factors}

\author{
Anticorpos anti-Toxocara em crianças admitidas na escola fundamental em Vitória, Estado \\ do Espírito Santo: prevalência e fatores associados
}

Roberta Paranhos Fragoso ${ }^{1}$, Mariza Buriche Macedo Monteiro ${ }^{1}$, Elenice Moreira Lemos ${ }^{2}$ and Fausto Edmundo Lima Pereira ${ }^{2}$

\begin{abstract}
Introduction: The aim of this study was to evaluate the frequency of anti-Toxocara antibodies in serum from 7-year-old children attending elementary school in Vitória-ES, Brazil and to correlate these antibodies with socio-demographic factors, the presence of intestinal helminths, blood eosinophil numbers, past history of allergy or asthma, and clinical manifestations of helminth infections. Methods: The detection of anti-Toxocara antibodies was performed using an ELISA (Cellabs Pty Ltd)on serum from 391 children who had already been examined by fecal examination and blood cell counts. Data from clinical and physical examinations were obtained for all children. Results: The prevalence of anti-Toxocara antibodies was $51.6 \%$, with no gender differences. No significant differences were observed between positive serology and the presence or absence of intestinal worms ( 60.3 and $51.7 \%$, respectively; $\mathrm{p}=0.286$ ). The only variables significantly related to positive serology were onycophagy and the use of unfiltered water. Although eosinophilia (blood eosinophil count higher than $600 / \mathrm{mm}^{3}$ ) was significantly related to the presence of a positive ELISA result, this significance disappeared when we considered only children without worms or without a past history of allergy or asthma. No clinical symptoms related to Toxocara infection were observed. Conclusions: There is a high prevalence of anti-Toxocara antibodies in children attending elementary schools in Vitória, which may be partially related to cross-reactivity with intestinal helminths or to a high frequency of infection with a small number of Toxocara eggs.
\end{abstract}

Keywords: Toxocara canis.Toxocariasis.Toxocara infection.Visceral larva migrans.

\section{RESUMO}

Introdução: $\mathrm{O}$ objetivo desse estudo foi avaliar a prevalência de anticorpos anti-Toxocara em crianças admitidas no primeiro ano de escola fundamental em Vitória e correlacionar com variáveis sociodemográficas, helmintos intestinais, eosinófilos no sangue, geofagia, onicofagia, história de asma e alergia cutânea e manifestações clínicas. Métodos: A pesquisa de anticorpos anti-Toxocara, utilizando um teste de ELISA (Cellabs), foi realizada em 391 crianças nas quais foram realizados exames parasitológicos de fezes e hemograma completo. Todas as crianças foram submetidas a exame clínico e físico. Resultados: A prevalência de reação positiva foi de $51,6 \%$, sem diferença entre os sexos. Não foram observadas diferenças significativas na prevalência de reação positiva em crianças com ou sem helmintos intestinais $(60,3$ e 51,7\%, respectivamente; $\mathrm{p}=0.286$ ). Ainda que a frequência de eosinófilos acima de $600 / \mathrm{mm}^{3}$ tenha sido significativamente maior em crianças com sorologia positiva, a significância desapareceu quando se considerou as crianças sem helmintos intestinais ou história pregressa de asma ou alergia cutânea. As únicas variáveis significativamente correlacionadas, de modo independente, com a presença de sorologia positiva foram onicofagia e hábito de beber água não filtrada. Nenhuma criança apresentou manifestação clínica relacionada com a presença de anticorpos anti-Toxocara. Conclusões: A prevalência de anticorpos anti-Toxocara em crianças admitidas nas escolas elementares em Vitória é alta, a qual pode estar, em parte, relacionada à reação cruzada com antígenos de helmintos intestinais ou devida a frequente exposição a baixas quantidades de ovos do Toxocara.

Palavras-chaves: Toxocara canis. Toxocarase. Infecção com Toxocara. Larva migrans visceral.

1. Serviço de Pediatria, Hospital Universitário Cassiano Antonio de Moraes, Universidade Federal do Espírito Santo, Vitória, ES. 2. Núcleo de Doenças Infecciosas, Centro de Ciências da Saúde, Universidade Federal do Espírito Santo, Vitória, ES.

Address to: Dr. Fausto Edmundo Lima Pereira. NDI/CCS/UFES. Av. Marechal Campos 1468, Maruípe, 29040-091 Vitória, ES, Brazil.

Phone: $55273335-7210$

e-mail: felp@ndi.ufes.br

Received in 06/01/2011

Accepted in 15/03/2011

\section{INTRODUCTION}

The prevalence of Toxocara infection as measured by evaluating anti-Toxocara antibodies in serum is variable, with higher prevalence observed in developing countries ${ }^{1-4}$. Some studies have demonstrated a positive correlation between the presence of anti-Toxocara antibodies and geophagy, onycophagy, a poor hygiene profile and contact with dogs ${ }^{4-7}$.

A highly variable prevalence has been reported in Brazil, largely based on descriptive studies using different samples (Table 1 summarizes the studies reporting the prevalence of anti-Toxocara antibodies in Brazil published from 1990 to $2009^{8-22}$ ). The only population-based study was published by Chieffi et $\mathrm{al}^{8}$, and this study reported a prevalence of $2.8-15.5 \%$ in children up to 15 years old from four different cities in the state of São Paulo.

A prevalence of $33.3-39 \%$ was reported in random samples of children at a Children's Reference Hospital in Vitória ${ }^{11,18}$. In this hospital, a significant association between staphylococcal infection and the presence of anti-Toxocara antibodies was reported ${ }^{23}$. In addition, larva migrans granulomas were observed in $3.2 \%$ of livers from routine autopsies at the same hospital ${ }^{24}$. Therefore, Toxocara infection appears to be prevalent in children from Brazil.

The Schoolchildren's Health Program of the municipality of Vitoria performs clinical examinations on all children in the first year of public elementary schools. A stool examination, a complete blood cell count and a hemoglobin evaluation are also performed. The aim of the present investigation was to assess the presence of anti-Toxocara antibodies in a representative number of these schoolchildren and to correlate these antibodies with clinical manifestations of infection, socio-economic patterns, hygiene profiles, eosinophil counts and the presence of intestinal helminths. 
TABLE 1 - Frequency of anti-Toxocara antibodies in children from different Brazilian cities.

\begin{tabular}{|c|c|c|c|}
\hline City & Sample & Frequency $(\%)$ & Reference \\
\hline Marília e Presidente Prudente (SP)* & $<15$ years $(\mathrm{n}=237)$ & 5.5 & - \\
\hline Recife (PE) & children/eosinophilia $(\mathrm{n}=54)$ & 40.0 & Virginia et al. ${ }^{9}$ \\
\hline Campo Grande (MS) & children/eosinophilia $(n=45)$ & 35.5 & Matos et al..$^{10}$ \\
\hline Campinas (SP) & children and adults $(\mathrm{n}=138)$ & 23.9 & Anaruma-Filho et al. ${ }^{12}$ \\
\hline São Paulo (Butantã) & school children $7-16$ years $(\mathrm{n}=399)$ & 38.8 & Alderete et al. ${ }^{7}$ \\
\hline Brasilia & children $1-12$ years $(n=302)$ & 21.8 & Campos Jr et al. ${ }^{13}$ \\
\hline Recife & children/adolescents $(\mathrm{n}=386)$ & 39.4 & Aguiar-Santos et al. ${ }^{14}$ \\
\hline Vitória (ES) & children $1-15$ years $(n=255)$ & 33.4 & Musso et al. ${ }^{18}$ \\
\hline Uberlândia (MG) & children $1-15$ years $(n=242)$ & 8.7 & Teixeira et al. ${ }^{19}$ \\
\hline Comunidade do Rio Uatumã (AM) & children and adults $0-76$ years $(n=100)$ & 52.0 & Damian et al. ${ }^{20}$ \\
\hline Maringá $(P R)$ & children 7 months -12 years $(n=450)$ & 28.8 & Paludo et al..$^{21}$ \\
\hline Ramal do Granada (AC) & children and adults 5-90 years $(n=403)$ & 26.8 & Rubinsky-Elefant et al. ${ }^{22}$ \\
\hline
\end{tabular}

\section{METHODS}

Serum samples were collected from 391 schoolchildren in the first year at eight elementary schools randomly selected from 39 schools located in low-income neighborhoods of Vitória. Sociodemographic data including age, gender, family income, parents' schooling, occurrence of geophagy and onycophagy, use of treated water and sewage facilities, and contact with dogs were collected in interviews with parents that agreed to participate in this investigation.

Stool examinations performed using the sedimentation method, blood cells counts and hemoglobin measurements were performed in the Central Laboratory of the municipality of Vitória. The blood cell counts and hemoglobin measurements were performed using automated instruments, with differential counts checked by Giemsastained smears. Aliquots of blood were collected for hematologic studies and were then centrifuged, and the sera were stored at $-20^{\circ} \mathrm{C}$ until use for anti-Toxocara antibody detection.

Anti-Toxocara antibodies were detected using a commercial test (Toxocara IgG ELISA, Cellabs Pty Ltd, Brookvale, Australia) that uses secretory/excretory antigens of the second stage larvae of Toxocara canis. The tests were performed according to the manufacturer's instructions. Samples with optical densities (OD) $\leq 0.500$ were considered negative, and samples with $\mathrm{OD}>0.500$ were considered positive.

All children were submitted to physical examination and their history of allergy or other disease was determined during an interview with their parents.

Statistical analysis was performed using SPSS 9.0 for Windows. The frequencies of the variables were calculated with $95 \%$ confidence intervals. Following statistical tests, $\mathrm{p}$ values $<0.05$ were considered significant.

\section{Ethical considerations}

The research was approved by the ethics committee of Centro de Ciências da Saúde, Universidade Federal do Espirito Santo.

\section{RESULTS}

The detection of anti-Toxocara antibodies was performed on serum from 391 children. Information pertaining to socio-economic status and sanitary conditions was obtained for approximately 340 of these children. All children were 7 years old, the age for admission to elementary schools in Vitória.

The results of the ELISA to measure anti-Toxocara antibodies are shown in Table 2, classified by gender and OD values in the ELISA. The overall prevalence of positive results (OD > 0.500) was $51.6 \%$, without significant gender differences.

A fecal examination was performed with 308 children, and 88 (28.5\%) children had at least one intestinal helminth. Ascaris lumbricoides was the most prevalent helminth in this study (53/88, $60.2 \%$ of intestinal helminths identified). Other identified helminths were Trichuris trichiura $(13 / 82,14.8 \%)$, Enterobius vermicularis $(11 / 82,12.5 \%)$ and Hymenolepis nana (11/88, 12.5\%).

Table 3 shows the ELISA results for anti-Toxocara antibodies in children with negative results upon fecal examination, positive results for at least one intestinal nematode and positive or negative results for Ascaris lumbricoides. Although the frequencies of positive antibody tests with different $\mathrm{OD}$ were higher in children with Ascaris infection, the differences were not statistically significant. The frequency of positive serology in children without helminth infections was $51.7 \%$ (116/224), similar to the overall frequency observed. As the parasite prevalence rates may be underestimated because a single stool sample per child was examined in this study, we also considered the children's past history of worm infection. When considering only children without worms and with no past history of worm infection, the prevalence of positive antibody test results was lower (51/109 or $46.7 \%$ ) but not significantly different from the overall prevalence observed (46.7 versus $51.7 \%$; $\mathrm{p}=0.428$ ). 
TABLE 2 - Results of ELISA tests to detect anti-Toxocara antibodies in 391 seven-year-old school children in public elementary schools from the urban periphery of Vitória, State of Espírito Santo, Brazil.

\begin{tabular}{|c|c|c|c|c|c|c|c|c|c|}
\hline \multirow[b]{2}{*}{ ELISA test (OD) } & \multicolumn{3}{|c|}{ All cases $(n=391)$} & \multicolumn{3}{|c|}{ Male $(n=206)$} & \multicolumn{3}{|c|}{ Female $(n=185)$} \\
\hline & $\mathrm{n}$ & $\%$ & (95\% CI) & $\mathrm{n}$ & $\%$ & $(95 \% \mathrm{CI})$ & $\mathrm{n}$ & $\%$ & (95\% CI) \\
\hline \multicolumn{10}{|l|}{ Negative tests* } \\
\hline$(\leq 0.500)$ & 189 & 48.4 & $(44.8-52.0)$ & 96 & 46.6 & $(41.6-51.6)$ & 93 & 40.3 & $(36.1-45.4)$ \\
\hline \multicolumn{10}{|l|}{ Positive tests ${ }^{*}$} \\
\hline$(0.501-1.00)$ & 92 & 23.5 & $(19.6-27.9)$ & 55 & 26.6 & $(20.6-32.6)$ & 37 & 40.3 & $(33.3-47.3)$ \\
\hline$(>1.00)$ & 110 & 28.1 & $(23.9-32.7)$ & 55 & 26.7 & $(20.6-32.8)$ & 55 & 29.7 & $(23.6-36.6)$ \\
\hline Total & 202 & 51.6 & $(46.7-56.5)$ & 110 & 53.4 & $(46.6-60.2)$ & 92 & 49.7 & $(42.6-56.8)$ \\
\hline
\end{tabular}

TABLE 3 -Results of ELISA tests for the detection of anti-Toxocara antibodies in 305 seven-year-old schoolchildren attending public elementary schools from the urban periphery of Vitória, State of Espírito Santo, Brazil, separated based on the presence or absence of intestinal helminths.

\begin{tabular}{|c|c|c|c|c|c|c|}
\hline \multirow{2}{*}{$\begin{array}{l}\text { ELISA test } \\
\text { (optical density) }\end{array}$} & \multicolumn{3}{|c|}{ Intestinal helminths } & \multicolumn{3}{|c|}{ Ascaris lunmbricoides } \\
\hline & negative & positive & $\mathrm{p}^{*}$ & negative & positive & $\mathrm{p}^{*}$ \\
\hline \multicolumn{7}{|l|}{ Negative } \\
\hline$(\leq 0.500)$ & 108 & 36 & $1.00^{\mathrm{a}}$ & 123 & 21 & $0.611^{\mathrm{a}}$ \\
\hline \multicolumn{7}{|l|}{ Positive } \\
\hline$(0.501-1.00)$ & 56 & 16 & & 60 & 12 & \\
\hline$(>1.00)$ & 60 & 29 & $0.200^{\mathrm{a}}$ & 69 & 20 & $0.477^{\mathrm{a}}$ \\
\hline All positive cases & 116 & 45 & $0.651^{b}$ & 129 & 32 & $0.286^{\mathrm{b}}$ \\
\hline \multicolumn{7}{|c|}{ 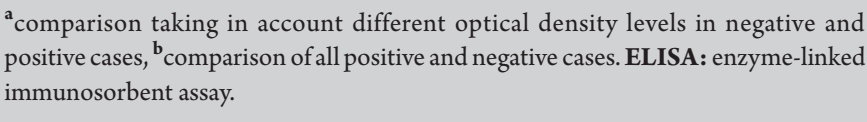 } \\
\hline${ }^{*} \chi_{2}$ test & & & & & & \\
\hline
\end{tabular}

As shown in Table 4, eosinophilia was frequent in the individuals studied ( 120 of 245 children had an eosinophil count higher than 600 cells $/ \mathrm{mm}^{3}$ ) and was detected significantly more often in children with positive serology for Toxocara. However, the presence of other intestinal helminths, skin allergy and asthma are important causes of eosinophilia in children. To verify whether a positive test for anti-Toxocara antibodies is a factor that influences peripheral blood eosinophil counts, the proportions of positive and negative antibody results were compared with the frequency of eosinophilia in children with and without intestinal helminths or a past history of skin allergy or asthma. There was no significant difference in eosinophil counts higher than 600 cells $/ \mathrm{mm}^{3}$ between the children with positive or negative anti-Toxocara antibody tests. Similarly, the presence of positive antibody test results did not influence the prevalence of eosinophilia in children with intestinal helminths or with a past history of allergy or asthma, thus confirming that the presence of anti-Toxocara antibodies in the serum was not associated with increased blood eosinophils in this sample.

The frequencies of positive antiToxocara antibody tests relative to socioeconomic status, sanitary conditions, onycophagy, geophagy and contact with dogs are summarized in Table 5. Low family income, onycophagy, presence of

${ }^{*}$ chi-square test with Yates correction. dogs in household and drinking non-filtered water was significantly associated with positive antibody tests. A multivariate analysis using a logistic regression demonstrated that drinking non-filtered water and onycophagy were independently associated with positive serology for Toxocara. Abnormalities upon physical examination were not found in any children in this study.

A past history of asthma, skin allergy and abdominal pain did not correlate with antibodies against Toxocara. Among 84 children with a past history of asthma and 85 children with a past history of skin allergy, anti-Toxocara antibodies were detected in 46 (54.7\%) and 42 (49.4\%), frequencies similar to those observed in children without a past history of asthma or skin allergy (86/171, 50.3\%; Chi-square test, $\mathrm{p}=0.475$ and 0.825 versus asthma and skin allergy).

TABLE 4 -Eosinophil counts in seven-year-old children from elementary schools in Vitoria, State of Espírito Santo, Brazil, with or without intestinal helminths or a past history of cutaneous allergy or asthma, according the presence or absence of a positive antibody test for Toxocara canis.

\begin{tabular}{|c|c|c|c|}
\hline \multirow[b]{2}{*}{ Groups } & \multicolumn{2}{|c|}{ Blood eosinophils $/ \mathrm{mm}^{3}$} & \multirow[b]{2}{*}{$\mathrm{p}^{*}$} \\
\hline & $<600$ & $>600$ & \\
\hline \multicolumn{4}{|l|}{ All cases $(n=336)$} \\
\hline anti-Toxocara $(+)$ & 93 & 87 & - \\
\hline anti-Toxocara (-) & 122 & 33 & 0.000 \\
\hline \multicolumn{4}{|c|}{ Without intestinal helminths or past history of skin allergy or asthma $(n=115)$} \\
\hline anti-Toxocara $(+)$ & 37 & 20 & - \\
\hline anti-Toxocara (-) & 44 & 14 & 0.114 \\
\hline \multicolumn{4}{|c|}{ With intestinal helminths or past history of skin allergy or asthma $(n=130)$} \\
\hline anti-Toxocara $(+)$ & 78 & 52 & - \\
\hline anti-Toxocara (-) & 74 & 61 & 0.403 \\
\hline
\end{tabular}


TABLE 5 - Gender, sanitary conditions and familial socio-economic status associated with the presence of a positive result in ELISA test for anti-Toxocara antibodies in serum samples from seven-year-old schoolchildren attending elementary school in of Vitória, State of Espírito Santo, Brazil.

\begin{tabular}{lllll}
\hline & \multicolumn{2}{c}{ ELISA test } & & \\
Variables & positive negative & OR $(95 \% \mathrm{CI})$ & $\mathrm{P}^{*}$ \\
\hline
\end{tabular}

\begin{tabular}{lrrrr}
\hline $\begin{array}{l}\text { Gender } \\
\text { male }\end{array}$ & 110 & 96 & & \\
female & 92 & 93 & $1.16(0.76-1.76)$ & 0.533 \\
\hline Mother's schooling & & & & \\
elementary & 61 & 58 & & \\
first degree & 73 & 63 & & \\
secondary & 32 & 36 & & \\
university & 1 & 3 & not applied & 0.420 \\
\hline
\end{tabular}

\begin{tabular}{lrrrr}
\hline Father's schooling & & & & \\
elementary & 60 & 60 & & \\
first degree & 69 & 62 & & \\
secondary & 39 & 28 & & 0.385 \\
university & 1 & 4 & not applied & \\
\hline Family income & 131 & 100 & & 0.008 \\
$<$ U\$300 & 44 & 63 & $1.88(1.15-3.07)$ & \\
$\geq$ U\$300 & & & & \\
\hline
\end{tabular}

\begin{tabular}{lrrrr} 
Geophagy & & & & \\
yes & 12 & 14 & & \\
no & 163 & 149 & $0.78(0.33-1.87)$ & 0.684 \\
\hline
\end{tabular}

\begin{tabular}{lrrrr}
\hline Onycophagy & & & & \\
yes & 115 & 83 & & \\
no & 60 & 80 & $1.85(1.16-2.93)$ & 0.008 \\
\hline
\end{tabular}

\section{Water facilities}

\begin{tabular}{lrrrrr} 
yes & 173 & 160 & & \\
no & 2 & 3 & $1.62(0.22-14.05)$ & 0.675 \\
\hline
\end{tabular}

\begin{tabular}{lrrrr} 
no & 2 & 3 & $1.62(0.22-14.05)$ & 0.675 \\
\hline Unfiltered water & & & & \\
yes & 51 & 13 & & \\
no & 124 & 150 & $4.75(2.37-9.64)$ & 0.001 \\
\hline
\end{tabular}

\begin{tabular}{lrrrr}
\hline $\begin{array}{l}\text { Sewage facilities } \\
\text { yes }\end{array}$ & 174 & 162 & & \\
no & 1 & 1 & $1.07(0.98-1.02)$ & 0,733 \\
\hline $\begin{array}{l}\text { Dog in the household } \\
\text { yes }\end{array}$ & 78 & 54 & & \\
no & 97 & 109 & $1.62(1.02-2.06)$ & 0.031 \\
\hline
\end{tabular}

*multivariate analysis by logistic regression. ELISA: enzyme-linked immunosorbent assay.

\section{DISCUSSION}

These results demonstrate a high prevalence of anti-Toxocara antibodies in seven-year-old children living in the urban periphery of Vitória. This prevalence was higher than that reported in other Brazilian studies but similar to that observed in Santo Amaro, SP ${ }^{16}$. Even excluding children with intestinal helminths, the frequency of positive serology was still high. Moreover, 110 children had ELISApositive results with $\mathrm{OD}>1.00$, considered by the assay manufacturer to be indicative of more recent infection.

Cross-reactivity against other helminth antigens may be responsible for the high frequency of positive ELISA tests for antiToxocara antibodies. This cross-reactivity does exist, mainly against A. lumbricoides ${ }^{25,26}$, and we did not adsorb the serum samples with other nematode antigens before performing the ELISA in this study. However, because the frequency of positive ELISA tests in children without worms was $51.7 \%$, similar to the overall frequency of positive test results, we believe that the high frequency of positive serology observed in this study is not due to cross-reactivity. Moreover, no differences were observed in the frequency of positive results between the individuals with and without intestinal worms or with and without A. lumbricoides(Table 3). This observation confirms that although cross-reactivity exists, the frequency of positive serology in children without intestinal worms is high. Although only one fecal sample per child was examined, our conclusion is strengthened by the observation of an increased percentage of positive antibody tests when we considered both children with parasites and children with a past history of worm infection. The cross-reactivity may be responsible for the frequent detection of ELISA-positive samples with high OD in asymptomatic children.

The high prevalence of anti-Toxocara antibodies in seven-year-old children is consistent with other studies performed in a children's hospital in Vitória. These studies reported prevalences from 30 to $39 \%$ of admitted children with positive antibody tests for Toxocara ${ }^{11,18}$, and $3.2 \%$ of livers obtained from routine autopsies had granulomas containing Toxocara antigens at the same hospital ${ }^{24}$.

In contrast to other reports ${ }^{7,11,12,16,21}$, we did not observe a significant difference for gender regarding the prevalence of positive tests for anti-Toxocara antibodies. These results are consistent with other studies showing no association between gender and risk of Toxocara infection ${ }^{22,27-29}$. However, positive correlations were observed between positive ELISA tests for Toxocara and low family income, the presence of dogs at home and onycophagia. These results are consistent with the results reported by other authors using samples from different Brazilian cities ${ }^{7,13-15}$. A multivariate analysis demonstrated that onycophagia and the use of unfiltered water were associated with positive antibody tests for Toxocara. An independent association between onycophagia and the presence of anti-Toxocara antibodies was also reported for children in São Paulo ${ }^{7}$. An association between the presence of anti-Toxocara antibodies and the use of unfiltered water has rarely been investigated. However, an investigation in the Amazonia did not reveal a correlation between positive serology for Toxocara and drinking unfiltered water ${ }^{22}$. Some authors have suggested the hypothesis that water contaminated with Toxocara eggs may have a role in Toxocara infection in humans ${ }^{30}$. It is possible that eggs transmitted by neighborhood dust from neighborhoods may contaminate water within the home. In accordance with this possibility, the presence of dog stool in areas near the dwellings was frequently observed during the visits to the children's homes.

Eosinophilia was observed in the samples studied and was more frequent in patientswith positive antibody test results for Toxocara. However, when we evaluated eosinophil counts in children without other causes of eosinophilia, such as intestinal worms, allergy or asthma, this difference disappeared. In accordance with this observation, there was no significant association between positive anti-helminth antibodies and eosinophil counts in children bearing intestinal worms or allergy. Thus, the results presented in this study demonstrate that the presence of anti-Toxocara antibodies in asymptomatic children is not an isolated factor that induces eosinophilia; the increased eosinophil counts in these cases are associated with the presence of other worms and or allergies. 
We did not find a correlation between positive antibody tests for

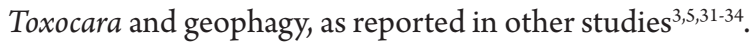

Although controversial, an association between allergic disorders and Toxocara infection has been reported ${ }^{7,34-37}$. In our sample, no significant association was found between the presence of positive serology for Toxocara and a past history of asthma or other allergic manifestations.

Clinical examination of all children did not demonstrate signs or symptoms that could be correlated with Toxocara infection. The absence of clinical manifestations in children with anti-Toxocara antibodies is consistent with the observation that the great majority of children that acquire Toxocara larvae develop silent infections with only rare manifestations of visceral or ocular larva migrans ${ }^{38,39}$.

In conclusion, the results reported here revealed high prevalence of anti-Toxocara antibodies in seven-year-old children living in the urban periphery of Vitória as detected by the ELISA using Toxocara canis secretory/excretory antigens, and this finding suggests that the rate of infection with this nematode in this population is high. Crossreactivity with other helminth infections may be partially responsible for the observed results, but the prevalence of positive antibody tests was high in children without intestinal worms or a past history of worm infection. Clinical manifestations related to Toxocara infection were not observed. The high prevalence of Toxocara antibodies reported here may be associated with past infections with small number of larvae or with memory responses after recurrent infections resulting in low larval load.

\section{ACKNOWLEDGMENTS}

We thank Rodrigo R. Rodrigues for suggestions and Fabíola Karla Correa Ribeiro for language corrections.

\section{CONFLICT OF INTEREST}

The authors declare that there is no conflict of interest.

\section{FINANCIAL SUPPORT}

This research was supported by Cia Siderúrgica de Tubarão-AcelorBrasil and Fundação de Apoio ao Hospital Universitário Cassiano A Moraes.

\section{REFERENCES}

1. Hermann N, Glickman LT, Schantz PM, Weston MG, Domanski LM. Seroprevalence of zoonotic toxocariasis in the United States: 1971-1973. Am J Epidemiol 1985; 122:890-896

2. Magnaval JF, Michault A, Calon N, Charlet JP. Epidemiology of human toxocariasis in La Reunion. Trans R Soc Trop Med Hyg 1994; 88:531-533.

3. Alonso JM, Bojanich MV, Chamorro M, Gorodner JO. Toxocara seroprevalence in children from a subtropical city in Argentina. Rev Inst Med Trop Sao Paulo 2000; 42:235-237.

4. Despommier D. Toxocariasis: clinical aspects, epidemiology, medical ecology, and molecular aspects. Clin Microbiol Rev 2003; 16:265-272.

5. Glickman LT, Magnaval JF. Zoonotic roundworm infections. Infect Dis Clin North Am 1993; 7:717-732.

6. Holland CV, O'Lorcain P, Taylor MR, Kelly A. Sero-epidemiology of toxocariasis in school children. Parasitology 1995; 110:535-545

7. Alderete JM, Jacob CM, Pastorino AC, Elefant GR, Castro AP, Fomin AB, et al. Prevalence of Toxocara infection in schoolchildren from the Butanta region, Sao Paulo, Brazil. Mem Inst Oswaldo Cruz 2003; 98:593-597.
8. Chieffi PP, Ueda M, Camargo ED, Souza AM, Guedes ML, Gerbi LJ, et al. Visceral larva migrans: a seroepidemiological survey in five municipalities of Sao Paulo state, Brazil. Rev Inst Med Trop Sao Paulo 1990; 32:204-210.

9. Virginia P, Nagakura K, Ferreira O, Tateno S. Serologic evidence of toxocariasis in northeast Brazil. Jpn J Med Sci Biol 1991; 44:1-6.

10. Matos MF, Militao DN, Brum MA, Omais M, Quiliao ME, Dorval ME, et al Presence of anti-Toxocara antibodies in children selected at Hospital Universitario, Campo Grande, MS, Brazil. Rev Inst Med Trop Sao Paulo 1997; 39:49-50.

11. Moreira-Silva SF, Leao ME, Mendonca HF, Pereira FE. Prevalence of antiToxocara antibodies in a random sample of inpatients at a children's hospital in Vitoria, Espirito Santo, Brazil. Rev Inst Med Trop Sao Paulo. 1998; 40:259-261.

12. Anaruma Filho F, Chieffi PP, Correa CR, Camargo ED, Silveira EP, Aranha JJ, et al. Human toxocariasis: a seroepidemiological survey in the municipality of Campinas (SP), Brazil. Rev Inst Med Trop Sao Paulo 2002; 44:303-307.

13. Campos Junior D, Elefant GR, Melo e Silva EO, Gandolfi L, Jacob CM, Tofeti A, et al. Frequency of seropositivity to Toxocara canis in children of different socioeconomic strata. Rev Soc Bras Med Trop 2003; 36:509-513.

14. Aguiar-Santos AM, Andrade LD, Medeiros Z, Chieffi PP, Lescano SZ, Perez EP. Human toxocariasis: frequency of anti-Toxocara antibodies in children and adolescents from an outpatient clinic for lymphatic filariasis in Recife, Northeast Brazil. Rev Inst Med Trop Sao Paulo 2004; 46:81-85.

15. Coelho LM, Silva MV, Dini CY, Giacon Neto AA, Novo NF, Silveira EP. Human toxocariasis: a seroepidemiological survey in schoolchildren of Sorocaba, Brazil. Mem Inst Oswaldo Cruz 2004; 99:553-557.

16. Figueiredo SD, Taddei JA, Menezes JJ, Novo NF, Silva EO, Cristovao HL, et al Clinical-epidemiological study of toxocariasis in a pediatric population.J Pediatr 2005 ; 8:126-132.

17. Muradian V, Gennari SM, Glickman LT, Pinheiro SR. Epidemiological aspects of Visceral Larva Migrans in children living at São Remo Community, Sao Paulo (SP), Brazil. Vet Parasitol 2005; 25:93-97.

18. Musso C, Lemos EM, Tsanaclis MC, Pereira EL. Toxocara infection associated with viral or bacterial infections of the central nervous system in children. Neuropediatrics 2006; 37:126-129

19. Teixeira CR, Chieffi PP, Lescano SA, Melo Silva EO, Fux B, Cury MC. Frequency and risk factors for toxocariasis in children from a pediatric outpatient center in southeastern Brazil. Rev Inst Med Trop Sao Paulo 2006; 48:251-255.

20. Damian MM, Martins M, Sardinha JF, Souza LO, Chaves A, Tavares AM. Frequency of the antibody anti-Toxocara canis in a community along the Uatumã river, State of Amazonas. Rev Soc Bras Med Trop 2007; 40:661-664.

21. Paludo ML, Falavigna DL, Elefant GR, Gomes ML, Baggio ML, Amadei LB, et al Frequency of Toxocara infection in children attended by the health public service of Maringá, south Brazil. Rev Inst Med Trop São Paulo 2007; 49:343-348.

22. Rubinsky-Elefant G, Silva-Nunes M, Malafronte RS, Muniz PT, Ferreira MU. Human toxocariasis in rural Brazilian Amazonia: seroprevalence, risk factors, and spatial distribution. Am J Trop Med Hyg 2008; 79:93-98.

23. Moreira-Silva SF, Leite AL, Brito EF, Pereira FE. Nematode infections are risk factors for staphylococcal infection in children. Mem Inst Oswaldo Cruz 2002; 97:395-399.

24. Musso C, Castelo JS, Tsanaclis AM, Pereira FE. Prevalence of Toxocara-induced liver granulomas, detected by immunohistochemistry, in a series of autopsies at a Children's Reference Hospital in Vitoria, ES, Brazil. Virchows Arch 2007; 450:411-417.

25. Nunes CM, Tundisi RN, Garcia JF, Heinemann MB, Ogassawara S, Richtzenhain LJ. Cross-reactions between Toxocara canis and Ascaris suum in the diagnosis of visceral larva migrans by western blotting technique Rev Inst Med Trop São Paulo $1997 ; 39: 253-256$

26. Romasanta A, Romero JL, Arias M, Sánchez-Andrade R, López C, SuárezJL, et al Diagnosis of parasitic zoonoses by immunoenzymatic assays-analysis of crossreactivity among the excretory/secretory antigens of Fasciola hepatica, Toxocara canis, and Ascaris suum. Immunol Invest 2003; 32:131-142

27. Glickman LT, Schantz PM, Cypess RH. Epidemiological characteristics and clinical findings in patients with serologically proven toxocariasis. Trans R Soc Trop Med Hyg 1979; 73:254-258.

28. Sadjjadi SM, Khosravi M, Mehrabani D, Orya A. Seroprevalence of toxocara infection in school children in Shiraz, southern Iran.J Trop Pediatr 2000; 46:327-330. 
29. Jimenez JF, Valladares B, Fernandez-Palacios JM, de Armas F, del Castillo AA. Serologic study of human toxocariasis in the Canary Islands (Spain): environmental influences. Am J Trop Med Hyg 1997; 56:113-115.

30. Beer SA, Novosil Tsev GI, Mel Nikova LI. The of water factor in the dissemination of Toxocara eggs and the spread of toxocariasis in a megalopolis. Parasitol 1999; 33:129-135.

31. Beaver PC, Snyder CH, Carrera GM, Dent JH, Lafferty JW. Chronic eosinophilia due to visceral larva migrans; report of three cases. Pediatrics 1952; 9:7-19.

32. Woodruff AW, DeSavigny D, Jacobs DE. Study of Toxocara infection in dog breeders. BMJ 1978; 2:1747-1748.

33. Schantz PM, Glickman LT. Toxocaral visceral larva migrans. N Engl J Med 1978 ; 298:436-439.

34. Chan PW, Anuar AK, Fong MY, Debruyne JA, Ibrahim J. Toxocara seroprevalence and childhood asthma among Malaysian children. Pediatr Int 2001; 43:350-353.

35. Jacob CM, Pastorino AC, Peres BA, Mello EO, Okay Y, Oselka GW. Clinical and laboratorial features of visceral toxocariasis in infancy. Rev Inst Med Trop São Paulo 1994; 36:19-26.

36. Buijs J, Borsboom G, van Gemund JJ, Hazebroek A, van Dongen PA, van Knapen F, Neijens HJ. Toxocara seroprevalence in 5-year-old elementary schoolchildren: relation with allergic asthma. Am J Epidemiol 1994; 140:839-847.

37. Gonzalez-Quintela A, Gude F, Campos J, Garea MT, Romero PA, Rey J, et al. Toxocara infection seroprevalence and its relationship with atopic features in a general adult population. Int Arch Allergy Immunol 2006; 139:317-324.

38. Agudelo C, Villareal E, Caceres E, Lopez C, Eljach J, Ramirez N, et al. Human and dogs Toxocara canis infection in a poor neighborhood in Bogota. Mem Inst Oswaldo Cruz 1990; 85:75-78.

39. Pawlowski Z. Toxocariasis in humans: clinical expression and treatment dilemma. J Helminthol 2001; 75:299-305. 